

\title{
EDITORA UNINGÁ
}

\section{ÓRGÃO DE DIVULGAÇÃO CIENTÍFICA MULTIDISCIPLINAR DA UNINGÁ - CENTRO UNIVERSITÁRIO INGÁ}

\author{
Reitor \\ Prof. Me. Roberto Cezar de Oliveira \\ Pró-Reitora Acadêmica \\ Prof. Me. Maria Albertina Ferreira do Nascimento \\ Diretora de Pós-graduação \\ Profa. Dra. Sandra Marisa Pelloso \\ Editor-chefe \\ Prof. Dr. Isaac Romani
}


(C) 2021 Editora UNINGÁ

Direção Editorial

Prof. Dr. Isaac Romani

Assistente Editorial:

Vitor Vinicius Monteiro Gajardoni

Diagramação:

Thiago Bruno Peraro
EDITORA

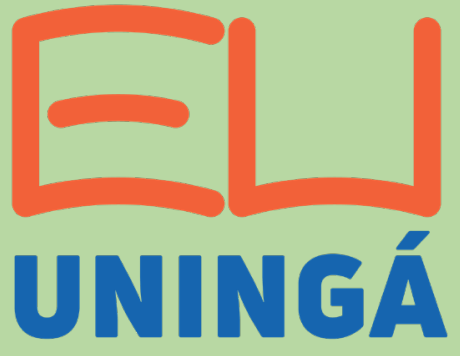

Dados Internacional de Catalogação na Publicação (CIP)

Bibliotecária: Vaudice Donizeti Rodrigues CRB 9/1726

Teston, Ana Paula Margioto.

T345m Manual técnico para preparo de formulações à base de álcool 70\%. [recurso eletrônico] / Ana Paula Margioto Teston e Daniela Cristina de Medeiros Araújo. -- Maringá: UNINGÁ, 2021. 30 p.

DOI: $10.46311 / 978-65-991603-8-7$

ISBN: 978-65-991603-8-7

1. Álcool 70\%. 2. Álcool gel. 3. Antissépticos. I. Teston, Ana

Paula Margioto. II. Araújo, Daniela Cristina de Medeiros. III. Título.

CDD-615.4

Todos os direitos reservados. Nenhuma parte desta obra poderá ser reproduzida, arquivada ou transmitida por qualquer meio ou forma sem prévia permissão por escrito da Editora UNINGÁ. 
MANUAL TÉCNICO PARA PREPARO DE FORMULAÇÕES À BASE DE ÁLCOOL 70\%

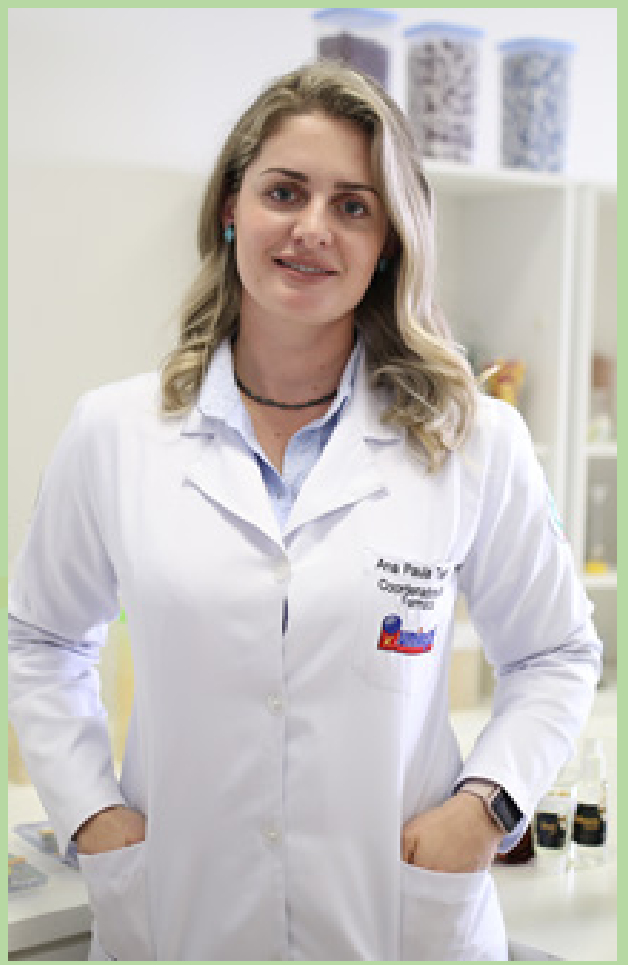

Profa. Dra. Ana Paula Margioto Teston

Farmacêutica. Pós-doutora em Ciências da Saúde pela Universidade Estadual de Maringá. UNINGÁ - Centro Universitário Ingá

(9)

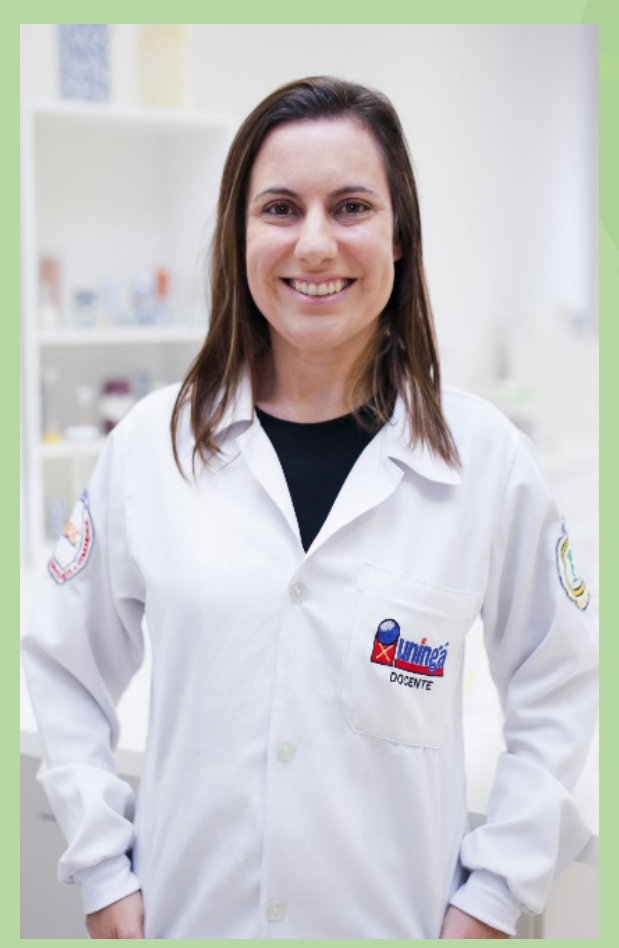

Prof ${ }^{\mathrm{a}}$. Dra . Daniela Cristina de Medeiros Araújo

Farmacêutica. Pós-doutora em Ciências Farmacêuticas pela Universidade Estadual de Maringá. UNINGÁ - Centro Universitário Ingá

(9) 


\section{APRESENTAÇÃO}

No início de 2020 foi decretada pandemia pelo novo coronavírus (SARS-Cov2; COVID-19), atingindo a maioria dos países do mundo. Milhares de pessoas já foram a óbito por complicações desta infecção ainda pouco conhecida, embora bastante estudada.

A Organização Mundial da Saúde, baseada em pesquisas recentes e no perfil do novo coronavírus, estabeleceu medidas profiláticas simples para evitar a disseminação viral. Dentre elas, está o uso de formulações à base de álcool 70\% para assepsia das mãos e desinfecção de superfícies (WHO, 2020).

Em tempos de fácil divulgação de informações falsas, errôneas, caseiras e empíricas através de redes sociais, viu-se a necessidade do fornecimento de conhecimento científico e adequado à população. Diante deste contexto, este manual técnico torna-se um importante instrumento para o preparo correto de formulações à base de álcool 70\%, comprovadamente eficaz para a eliminação do novo coronavírus (SARS-Cov2) e de outros microrganismos, quando utilizado nas mãos e nos ambientes.

Neste manual são abordadas terminologias, técnicas de preparo com riqueza de detalhes e imagens, controle de qualidade e rotulagem das formulações elaboradas e destinadas a técnicos de laboratórios, estudantes, profissionais de saúde e a quem interessar sobre o preparo correto destas formulações.

O objetivo principal é garantir que as formulações à base de álcool 70\% realmente sejam efetivas na eliminação de SARS-Cov2 e de outras infecções. Assim, a produção de álcool 70\% está intimamente relacionada a uma preparação criteriosa e adequada. Tais cuidados trazem confiança e segurança na utilização destas formulações e contribuem para a saúde pública.

O Manual Técnico para Preparo de Formulações à base de Álcool tem por objetivo fornecer informações científicas para o preparo adequado de álcool 70\% nas formas de líquido e gel, que garantam a eficácia da eliminação de vírus e bactérias. Baseado em formulações oficiais e nas recomendações da Organização Mundial da Saúde, a metodologia empregada fornece o passo-a-passo com imagens e riqueza de detalhes para que este manual seja utilizado como roteiro de laboratório, a fim de facilitar a preparação de tais formulações.

Inicialmente, apresenta-se uma introdução com a descrição dos principais processos envolvendo microrganismos, bem como os principais antissépticos para mãos e superfícies. Na segunda seção, são estabelecidas as terminologias das preparações, com a diferenciação das definições referentes às graduações alcoólicas (GL, INPM, \% p/p).

$\mathrm{Na}$ terceira seção, é descrita a metodologia completa para o preparo de álcool líquido $70 \%$ (massa) e álcool líquido 77\% (volume), os quais correspondem à mesma concentração e ao mesmo efeito, porém, diferem na técnica de preparo, assim como a aplicação desses para a formulação em gel. Nesta seção consta também o preparo de antisséptico para mãos e superfícies segundo a OMS.

A quarta seção descreve o preparo adequado de cada formulação, bem como os critérios para o controle de qualidade de tais formulações para a garantia do grau alcóolico pretendido no preparo da formulação.

E finaliza-se com a quinta seção que se refere a algumas informações importantes a serem incluídas na rotulagem das formulações para fins de orientação ao consumidor e garantia do uso correto e seguro das mesmas. 


\section{SUMÁRIO}

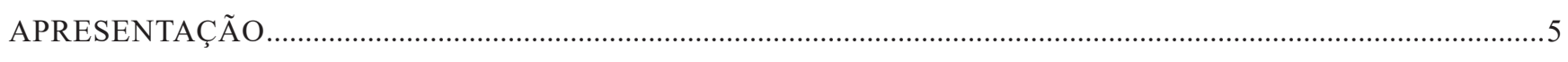

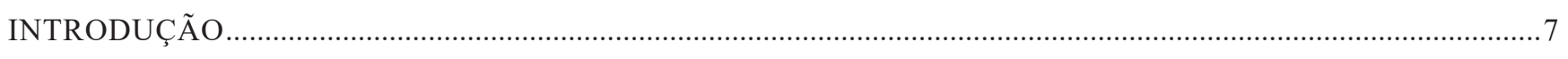

DEFINIÇÕES DE PROCESSOS ENVOLVENDO MICRORGANISMOS .................................................................

PRINCIPAIS ANTISSÉPTICOS UTILIZADOS NAS MÃOS E SUPERFÍCIES …………………...............................

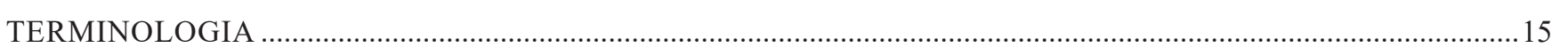

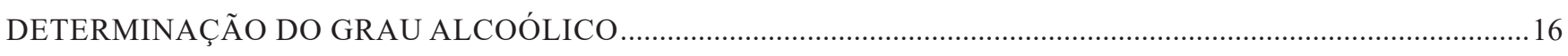

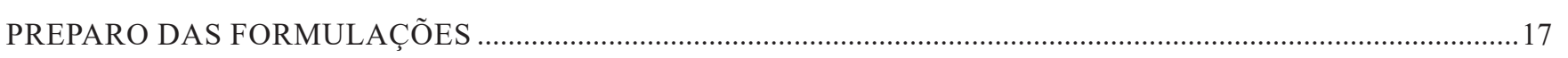

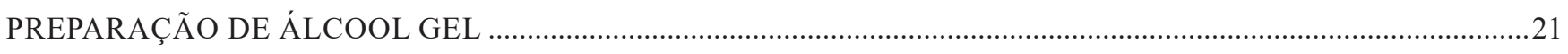

PREPARAÇÃO DE ANTISSÉPTICO PARA MÃOS E SUPERFÍCIES SEGUNDO A ORGANIZAÇÃO MUNDIAL

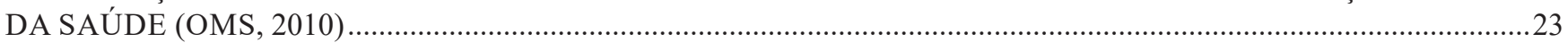

INFORMAÇÕES GERAIS - ROTULAGEM

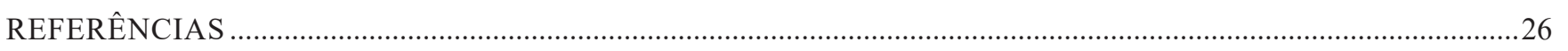




\section{INTRODUÇÃO}

Desde os primórdios, profissionais da área da saúde e muitos cientistas lutam contra as infecções, na expectativa de reduzir as taxas de mortalidade por elas causadas. Ao longo da história, essas lutas nem sempre foram de sucesso para o ser humano, porém, foram diminuindo ao passo que medidas relacionadas à limpeza, à higiene de ambientes e aos alimentos foram sendo implantadas, que evoluíram para a atual desinfecção, esterilização e antissepsia (KALIL; COSTA, 1994).

Algumas medidas devem ser tomadas para que seja evitada a transmissão de microrganismos de pessoa para pessoa, seja em ambientes comuns ou hospitalares. Vale ressaltar que a limpeza das mãos com água e sabão é essencial como medida diária para a prevenção de várias doenças transmissíveis. Se considerado um ambiente clínico ou hospitalar, medidas de limpeza, desinfecção, esterilização e acondicionamentos adequados de material e lixo hospitalares tornam-se cruciais no combate às infecções (BRASIL, 2010; BERNARDI; COSTA, 2017).

\section{DEFINIÇÕES DE PROCESSOS ENVOLVENDO MICRORGANISMOS}

A Agência Nacional de Vigilância Sanitária (ANVISA) publicou um manual em 2012 que trata sobre a correta limpeza e desinfecção de superfícies em serviços de saúde, com o intuito de orientar e estabelecer normas. O manual disponibilizou informações atualizadas e algumas definições devem ser conhecidas em relação aos processos que envolvem microrganismos:

\section{Limpeza}

Consiste na remoção de materiais estranhos aos objetos (como sujeiras, sangue, saliva, fragmentos de tecidos orgânicos, secreções, etc.) com água, podendo também utilizar-se de algum tipo de sabão ou detergente. Obrigatoriamente, a limpeza deve anteceder a desinfecção e a esterilização (KALIL; COSTA, 1994; ANVISA, 2012).

\section{Desinfecção}

É o processo que promove a eliminação de todos os microrganismos ou objetos inanimados patológicos, com exceção dos endósporos bacterianos. Difere da esterilização pelo fato de não eliminar totalmente todas as formas de vida microbiana. Alguns desinfetantes, chamados quimioesterilizadores, podem eliminar os esporos bacterianos se a exposição ocorrer por tempo prolongado (de 6 a 10 horas), conhecidos como desinfetantes de alto nível. Os desinfetantes germicidas podem ser diferidos quanto ao espectro antimicrobiano e à rapidez com que agem (KALIL, COSTA, 1994; ANVISA, 2012).

\section{Esterilização}

Consiste na utilização de técnicas que promovam a eliminação total dos microrganismos, incluindo os esporos bacterianos, contudo, são necessários a utilização de agentes degermantes e tempo adequados. O processo deve ser monitorado para garantia do objetivo (KALIL; COSTA, 1994; ANVISA, 2012). 


\section{Descontaminação}

É o processo pelo qual os microrganismos patológicos de um objeto são removidos, considerado como seguro para ser manuseado pelos profissionais competentes (KALIL; COSTA, 1994; ANVISA, 2012).

\section{Antissepsia}

Consiste em medidas que promovem a inibição do crescimento de microrganismos ou a remoção desses de determinado ambiente ou superfície, capazes de destruí-los ou apenas removê-los. Para tal finalidade, devem-se utilizar antissépticos ou desinfetantes (MORIYA; MÓDENA, 2008).

\section{Assepsia}

É um conjunto de medidas que visam impedir a contaminação de um ambiente por microrganismos, considerando que o lugar esteja livre deles. Portanto, um ambiente asséptico é aquele livre de microrganismos (MORIYA, MÓDENA, 2008). 


\section{PRINCIPAIS ANTISSÉPTICOS UTILIZADOS NAS MÃOS E SUPERFÍCIES}

Para as mãos, os antissépticos com detergente (degermantes) são utilizados com frequência, pois promovem a remoção de detritos e impurezas, com antissepsia parcial. Por exemplo, a solução detergente de PVPI 10\% (polivinilpirrolidona com iodo ativo 1\%); Solução de clorhexidina a $4 \%$, com 4\% de álcool etílico. Já as soluções de álcool $70 \%$ iodado a $0,5 \%$ e álcool etílico $70 \%$ com $2 \%$ de glicerina promovem efetivamente a antissepsia das mãos e especialmente esta última, além de não deixarem resíduos (MORIYA; MÓDENA, 2008).

\section{Compostos de iodo}

Os compostos de iodo possuem ação bactericida, fungicida e algumas vezes fungicida. No entanto, a ação total deles está condicionada ao ambiente como a quantidade de matéria orgânica, que está presente. O composto mais utilizado é o álcool iodado a 1\% ou 5\%. A combinação com o álcool $70 \%$ potencializa a ação do antisséptico (KALLIL; COSTA, 1994; MORIYA; MÓDENA, 2008).

\section{Iodóforos}

A combinação de polivinilpirrolidona com iodo ativo 1\%, além de manter ativa a ação germicida do iodo, apresenta algumas vantagens do que quando o iodo está em soluções alcoólicas ou aquosas. Não mancha, não queima, possui ação germicida residual e não provoca reações alérgicas (KALLIL; COSTA, 1994; MORIYA; MÓDENA, 2008).

\section{Clorhexedina}

A clorhexedina (1, 6 di 4-clorofenil-di-guanidohexano) é um germicida com maior ação sobre bactérias Gram-positivas. Um excelente substituto para os casos em que a pessoa tem alergia ao iodo. Sua ação é imediata, com baixa toxicidade, não é absorvida pela pele e mantém efeito germicida residual. A solução de clorhexedina com álcool 70\% possui maior potência devido à combinação de efeitos germicidas (KALLIL; COSTA, 1994; MORIYA; MÓDENA, 2008).

\section{Cloro e derivados clorados}

Dentre os mais potentes germicidas, (o cloro e derivados clorados) agem por oxidação de enzimas e aminoácidos, inibem a síntese de proteínas, promovem quebra do DNA, alteração de componentes celulares e redução de oxigênio e nutrientes; além de promovem toxicidade em qualquer matéria viva. São muito utilizados para antissepsia de objetos, água de abastecimento e até tecidos. Em pH alcalino e na presença de muita matéria orgânica, a ação do cloro e seus derivados pode ser anulada. Dentre seus derivados, a solução mais utilizada é a de hipoclorito de sódio a 5\% (KALLIL; COSTA, 1994; MORIYA; MÓDENA, 2008; PSALTIKS et al., 2011).

$\mathrm{Na}$ concentração de 1\% (1000ppm), a solução de hipoclorito de sódio tem baixa estabilidade, deve ser preparada com frequência antes do uso e abrigada por pouco tempo em recipiente que impeça passagem de luz (PSALTIKS et al., 2011). 
Sabões e detergentes

Usados para a lavagem das mãos, os sabões promovem a remoção de sujidades, matéria orgânica e impurezas da pele e outras superfícies. Podem conter antissépticos em concentração suficiente para remoção de microrganismos. Recomenda-se que, em estabelecimentos de saúde, sejam utilizados preferencialmente sabonetes líquidos ao invés de sabonetes em barra, pois evitam-se o contato direto com o produto e o risco de contaminação do mesmo (KALLIL; COSTA, 1994; MORIYA; MÓDENA, 2008).

\section{Peróxido de Hidrogênio}

Também conhecido como água oxigenada, atua na liberação de oxigênio quando em contato com enzimas presentes no sangue (catalases). Este oxigênio nascente possui ação germicida, tornando o peróxido de hidrogênio excelente para limpeza de feridas e superfícies com material biológico (KALLIL; COSTA, 1994; MORIYA; MÓDENA, 2008).

\section{Ácido peracético}

É um germicida de ação rápida que promove a ruptura da parede celular, oxidação e desnaturação das proteínas dos microrganismos. É um ácido muito utilizado para a desinfecção química de objetos hospitalares, pelo fato de atender à finalidade e ter baixo risco ocupacional (PSALTIKS et al., 2011).

\section{Álcool}

Os álcoois, etílico e isopropílico, podem ser adquiridos em diversas concentrações, porém entre 70 e 92\% (em massa) exercem ação germicida quase imediata, porém sem ação residual. O álcool etílico possui ação bactericida, atua na coagulação das proteínas de bactérias e promove a morte das mesmas. Do mesmo modo, possui ação fungicida e virucida, justificando a combinação de soluções alcoólicas a outros antissépticos para aumento de potência e eficácia. No entanto, não elimina endósporos e vírus não envelopados (MORIYA; MÓDENA, 2008; TORTORA et al., 2017; ARAÚJO et al., 2019).

A ação bactericida dos álcoois está relacionada à sua massa molecular. O álcool etílico tem maior eficácia na concentração de $70 \%$ e estas propriedades são atribuídas ao fato de causar desnaturação das proteínas quando na presença de água equivalente a $30 \%$. O etanol puro possui menos eficiência do que as soluções aquosas, pois a desnaturação proteica necessita de ótima concentração da água. Do mesmo modo, soluções alcóolicas abaixo de $50 \%$ perdem efetivamente a capacidade de eliminar os microrganismos (TORTORA, et al., 2017; ARAÚJO et al., 2019).

O álcool 70\% é um dos antissépticos mais utilizados no mundo, pois além de ser um bom germicida, possui baixo custo, fácil aquisição, fácil aplicação e toxicidade reduzida, tornando-se viável para combinações em nível hospitalar bem como para o uso comum em clínicas, consultórios e residências (KALLIL; COSTA, 1994; SANTOS et al., 2002; BRASIL, 2010; GRAZIANO et al., 2013; ARAÚJO et al., 2019).

Comumente, as formulações à base de álcool para antissepsia de mãos e superfícies são encontradas em gel ou líquidas. As mesmas podem ser adquiridas em estabelecimentos comerciais, no entanto, devem atentar-se as concentrações alcóolicas, devendo estar o mais próximo de 70\% para maior eficácia. 
Formulações próximas a 40\% são encontradas em supermercados para uso doméstico, porém, deve-se lembrar que elas não podem ser utilizadas exclusivamente como antissépticos, pois a concentração não permite tal efeito, sendo, portanto, indicadas apenas para limpeza. As formulações alcóolicas em gel são destinadas ao uso nas mãos e pele, pois a textura apresentada reduz o risco de incêndio e queimaduras. Já a formulação líquida é mais destinada à limpeza de superfícies, pela facilidade de aplicação. O álcool gel também pode ser usado para superfícies, porém apresenta a seguinte desvantagem - quando o álcool evapora, o gel fica preso à superfície, e assim é possível o acúmulo de sujeiras e microrganismos (PARANÁ, 2009; ARAÚJO et al., 2019).

A utilização contínua de formulações à base de álcool etílico pode promover o ressecamento da pele, o que pode ser minimizado e até evitado adicionando-se glicerina a $2 \%$ à formulação.

Como a remoção de sujidades é imprescindível ao sucesso da ação do álcool 70\% e dos demais antissépticos, a lavagem das mãos de forma correta torna-se crucial. Portanto, antes de utilizar álcool 70\% nas mãos, seja em gel ou líquido, o ideal é que seja feita a lavagem correta delas. Somente em situações em que a lavagem com água e sabão não estiver disponível é que se faz o uso direto das soluções alcoólicas sobre as mãos. E, para complementar o assunto, seguem abaixo as orientações da ANVISA (2012), sobre a lavagem correta das mãos (Figura $1-11$ ).

Figura 1 - Abrir a torneira e molhar as mãos, evitando encostar-se a pia

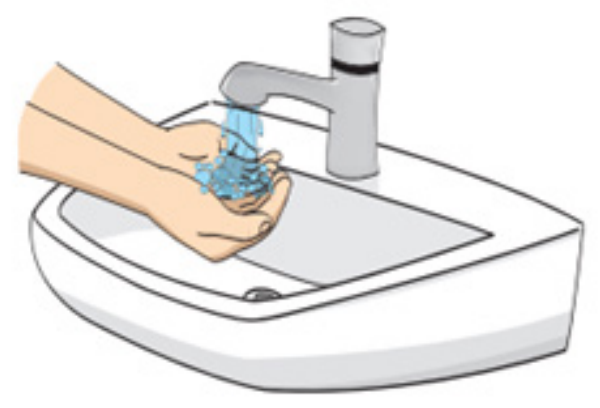

Fonte: Agência Nacional de Vigilância Sanitária (2012).

Figura 2 - Aplicar na palma da mão quantidade sufuciente de sabonete líquido para cobrir todas as superfícies da mão (seguir a quantidade recomendada pelo fabricante)

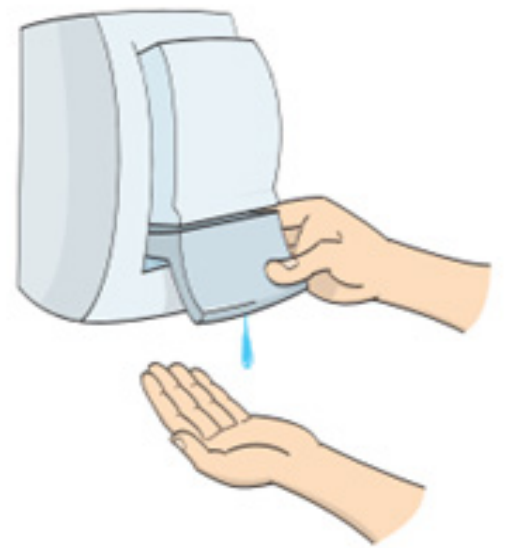

Fonte: Agência Nacional de Vigilância Sanitária (2012). 
Figura 3 - Ensaboar as palmas das mãos, friccionando-as entre si

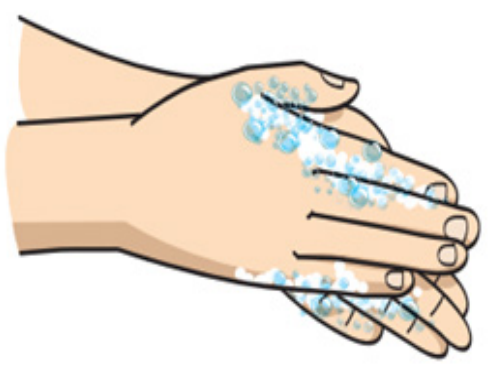

Fonte: Agência Nacional de Vigilância Sanitária (2012).

Figura 4 - Esfregar a palma da mão direita contra o dorso da mão esquerda, entrelaçando os dedos e vice-versa

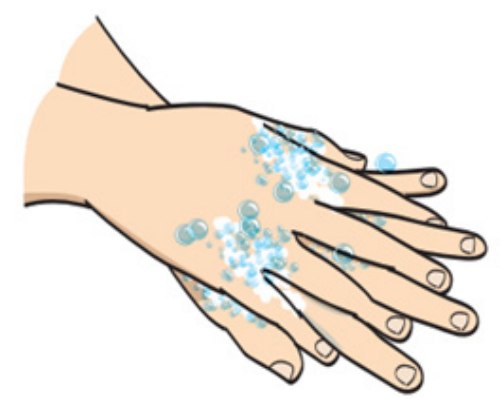

Fonte: Agência Nacional de Vigilância Sanitária (2012).

Figura 5 - Entrelaçar os dedos e friccionar os espaços interdigitais

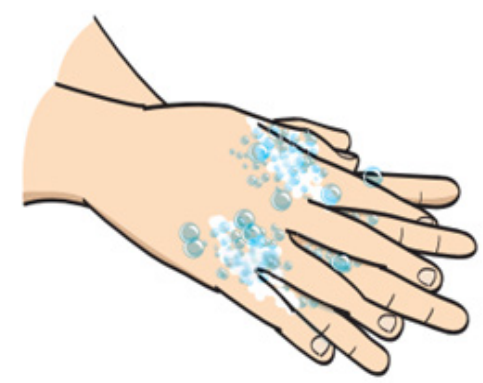

Fonte: Agência Nacional de Vigilância Sanitária (2012). 
Figura 6 - Esfregar o dorso dos dedos de uma mão com a palma da mão oposta, segurando os dedos, com movimento de vai-e-vem e vice-versa

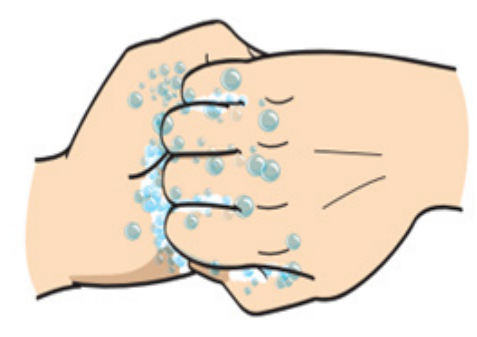

Fonte: Agência Nacional de Vigilância Sanitária (2012).

Figura 7 - Esfregar o polegar direito, com o auxílio da palma da mão esquerda, utilizando-se movimento circular e vice-versa.

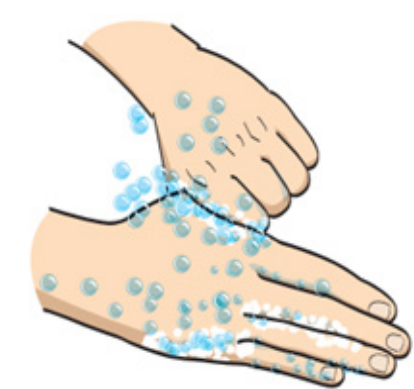

Fonte: Agência Nacional de Vigilância Sanitária (2012).

Figura 8 - Friccionar as polpas digitas e unhas da mão esquerda contra a palma da mão direita, fechada em concha, fazendo movimento circular e vice-versa

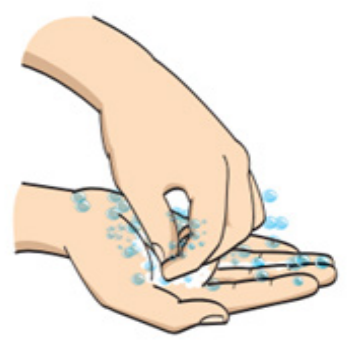

Fonte: Agência Nacional de Vigilância Sanitária (2012). 
Figura 9 - Esfregar o punho esquerdo com o auxílio da palma da mão direita, utilizando movimento circular e vice-versa

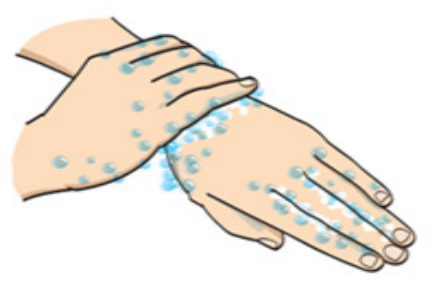

Fonte: Agência Nacional de Vigilância Sanitária (2012).

Figura 10 - Enxaguar as mãos retirando os resíduos de sabonete, no sentido dos dedos para os punhos.

Evitar o contato direto das mãos ensaboadas com a torneira

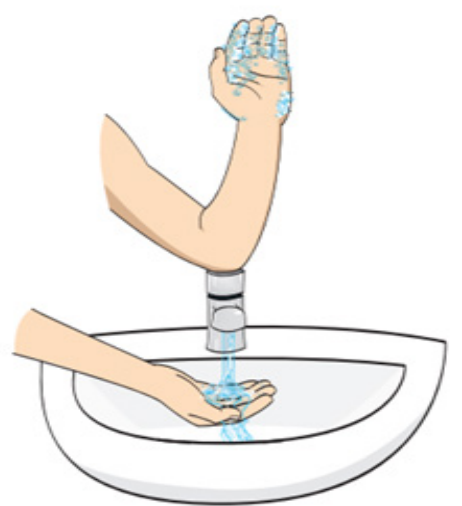

Fonte: Agência Nacional de Vigilância Sanitária (2012).

Figura 11 - Secar as mãos com papel-toalha descartável, iniciando pelas mãos e seguindo pelos punhos.

Desprezar o papel-toalha na lixeira para resíduos comuns

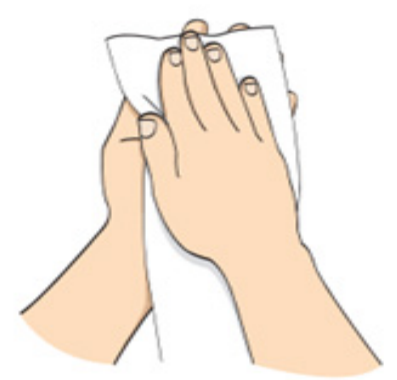

Fonte: Agência Nacional de Vigilância Sanitária (2012). 


\section{TERMINOLOGIA}

As unidades comerciais mais utilizadas serão apresentadas neste item, porém outras unidades podem ser encontradas.

\section{Graus GL}

O Grau Gay Lussac $\left({ }^{\circ} \mathrm{GL}\right)$ representa a porcentagem de álcool etílico em volume, ou seja, volume de álcool em mililitros presente em $100 \mathrm{~mL}$ de uma mistura de álcool e água. Esta concentração também pode ser expressa em \% (v/v) (BRASIL, 2012). Por exemplo: uma solução $80^{\circ} \mathrm{GL}$ possui $80 \mathrm{~mL}$ de álcool etílico em 100 mL da solução (mistura de álcool e água) (BRASIL, 2012).

\section{Grau INPM}

O Grau INPM (Instituto Nacional de Pesos e Medidas) representa a porcentagem de álcool etílico em massa, ou seja, a massa de álcool em gramas presente em 100 gramas de uma mistura de álcool e água. Esta concentração também pode ser expressa em \% (m/m, massa) (BRASIL, 2012). Por exemplo: uma solução $90^{\circ}$ INPM possui $90 \mathrm{~g}$ de álcool etílico em $100 \mathrm{~g}$ da solução (mistura de álcool e água) (BRASIL, 2012). OBS: álcool 70\% (massa) é o mesmo que álcool $77^{\circ} \mathrm{GL}$ (volume). 


\section{DETERMINAÇÃO DO GRAU ALCOÓLICO}

A determinação do grau alcoólico de misturas de álcool etílico e água é chamada de alcoometria. O instrumento utilizado para medida é o densímetro Gay-Lussac (alcoômetro), que indica a concentração do álcool em volume na solução. Sendo assim, as medidas do alcoômetro são exatas somente à temperatura de $20^{\circ} \mathrm{C}$ (temperatura de graduação do instrumento). Se a temperatura no momento da análise for diferente de $20^{\circ} \mathrm{C}$, é necessário corrigir o valor aferido pelo instrumento, utilizando a tabela da força real dos líquidos espirituosos (Anexo 1) (ANVISA, 2019).

\section{Procedimento para determinação do grau alcoólico}

a) Utilize recipiente volumétrico adequado (proveta) para verter a solução preparada de álcool etílico; E deixar em repouso até que desapareçam as bolhas;

b) Utilize um termômetro calibrado para verificar a temperatura do álcool etílico (temperatura aparente);

c) Um alcoômetro rigorosamente limpo e seco deve ser imergido no álcool em teste; $\mathrm{O}$ alcoômetro não deve encostar nas laterais nem no fundo do recipiente. Deve flutuar livremente;

d) Quando o alcoômetro atingir a posição de equilíbrio, é preciso verificar o ponto de afloramento da haste e ler o número da graduação na parte inferior do menisco. Essa leitura determina o grau alcoólico aparente contido na amostra, em centésimos e em volume;

e) Com as informações de temperatura e grau aparente projetadas na tabela da Força real dos líquidos espirituosos - Anexo 1, será possível obter o grau real da solução, de forma a corrigir a leitura obtida.

*Observações: A graduação alcoólica do álcool etílico absoluto deverá ser, no mínimo, 94,7 ${ }^{\circ} \mathrm{GL}$ ou $94,7 \%(\mathrm{v} / \mathrm{v})$ a $15^{\circ} \mathrm{C}$. O alcoômetro centesimal está calibrado à $20^{\circ} \mathrm{C}$ e, na Farmacopeia Brasileira, há indicação dos títulos etanólicos a $15^{\circ} \mathrm{C}$. Por isso é necessário proceder à conversão com base na Tabela da Força real dos líquidos espirituosos - Anexo 1 (ANVISA, 2019). 


\section{PREPARO DAS FORMULAÇÕES}

Preparo do álcool a $70^{\circ}$ INPM a partir de medidas de massa

\section{Material necessário:}

$\checkmark$ Vidrarias: béquer compatível com a massa de álcool a ser pesada e bastão de vidro para mistura.

$\checkmark$ Balança semianalítica;

$\checkmark$ Termômetro;

$\checkmark$ Alcoômetro;

$\checkmark$ Tabela dos Líquidos Espirituosos (Anexo 1);

$\checkmark$ Tabela alcoométrica (Anexo 2).

$\checkmark$ EPIs: luvas, máscara, jaleco de manga longa, calçado fechado.

\section{Procedimento}

A primeira etapa a ser realizada no preparo do álcool a $70 \%(\mathrm{p} / \mathrm{p})$, a partir do álcool etílico a 96 ${ }^{\circ} \mathrm{GL}$, é a verificação do grau alcoólico real. Para isto, se faz necessária a utilização da tabela dos líquidos espirituosos (Anexo 1). É necessária também a utilização de um termômetro para verificar a temperatura do álcool etílico $96^{\circ} \mathrm{GL}$.

As etapas seguintes serão descritas utilizando o exemplo abaixo.

Exemplo: Para preparar $1000 \mathrm{~g}$ de álcool 70\% (p/p), a partir do álcool etílico $96^{\circ} \mathrm{GL}$, que está à temperatura de $21^{\circ} \mathrm{C}$ :

a) Ao verificar os valores $96^{\circ} \mathrm{GL}$ e $21^{\circ} \mathrm{C}$ na tabela dos líquidos espirituosos (Anexo 1), você verá que os pontos se cruzam em 94,7 , portanto, o grau real deste álcool é $94,7^{\circ} \mathrm{GL}$ a $15^{\circ} \mathrm{C}$ (BRASIL, 2012)

b) Consultar então a tabela alcoométrica (Anexo 2) para determinar o título ponderal do álcool com 94,7 ${ }^{\circ} \mathrm{GL}$ (aproximar para $95^{\circ} \mathrm{GL}$ ). Ao se fazer a correlação entre a $1^{\circ}$ coluna e a $3^{\circ}$ coluna da tabela, verificase que o título ponderal do álcool a $95^{\circ} \mathrm{GL}$ é $92,43 \mathrm{~g}$;

c) Calcular a quantidade (em g) de álcool etílico a ser pesado utilizando a Equação 1 (BRASIL, 2012);

$$
\mathrm{T} 1 \times \mathrm{P} 1=\mathrm{T} 2 \times \mathrm{P} 2
$$

Onde:

P1: X massa (em g) de álcool a ser pesado;

T1: título ponderal do álcool etílico (corrigido pela tabela alcoométrica - Anexo 2)

T2: título ponderal que se deseja obter $(70 \% \mathrm{p} / \mathrm{p})$

P2: massa (em g) de álcool que se deseja preparar 


$$
\begin{aligned}
& \text { Ao se adequar o exemplo acima à fórmula: } \\
& \mathrm{T} 1=92,43 \mathrm{~g} \\
& \mathrm{P} 1=\mathrm{Xg} \\
& \mathrm{T} 2=70 \% \mathrm{p} / \mathrm{p} \\
& \mathrm{P} 2=1000 \mathrm{~g} \\
& \mathrm{~T} 1 \times \mathrm{P} 1=\mathrm{T} 2 \mathrm{X} \mathrm{P} 2 \\
& \left.1^{\circ}\right) 92,43 \times \mathrm{X}=70 \times 100 \\
& \left.2^{\circ}\right) 92,43 \mathrm{X}=70000 \\
& \left.3^{\circ}\right) \mathrm{X}=70000 / 92,43 \\
& \left.4^{\circ}\right) \mathrm{X}=755,32 \mathrm{~g} \text { de álcool etílico }
\end{aligned}
$$

Portanto, devem-se pesar 757,32 g de álcool etílico $\left(96^{\circ} \mathrm{GL}\right)$, completar para $1000 \mathrm{~g}$ com água destilada ou deionizada e homogeneizar a solução para que se obtenha uma formulação de álcool líquido $70 \%$ $\mathrm{p} / \mathrm{p}$.

d) Colocar o alcoômetro na solução preparada para conferir o grau alcoólico real, utilizando a tabela dos líquidos espirituosos (Anexo 1). O grau alcoólico não deverá ser menor que $76,9^{\circ} \mathrm{GL}$ e não mais que $81,4^{\circ} \mathrm{GL}$ (BRASIL, 2012). É preciso proceder o controle de qualidade conforme descrito no item 3 deste manual.

Ao término do procedimento de preparação, o álcool deve ser armazenado em recipiente de plástico opaco de alta densidade ou vidro âmbar, fechado e ao abrigo da luz, à temperatura ambiente. Deve ser mantido distante de fontes de calor e fora do alcance de crianças. Prazo de validade de seis meses (BRASIL, 2012)

\section{Preparação do álcool a $70^{\circ}$ INPM a partir de medidas de volume}

\section{Material necessário:}

$\checkmark$ Vidrarias: proveta compatível com o volume a ser preparado, béquer e bastão de vidro para mistura.

$\checkmark$ Alcoômetro;

$\checkmark$ Termômetro;

$\checkmark$ Tabela dos líquidos espirituosos;

$\checkmark$ Caneta e papel;

$\checkmark$ EPIs: luvas, máscara, jaleco de manga longa, calçado fechado. 


\section{Procedimento:}

Para preparar $1 \mathrm{~L}$ de álcool $77 \%(\mathrm{v} / \mathrm{v})$ ou $77^{\circ} \mathrm{GL}$ :

a) Em uma proveta de $1000 \mathrm{~mL}$, adicione $1000 \mathrm{~mL}$ de álcool e aguarde a saída das bolhas;

b) Coloque o alcoômetro e verifique a leitura aparente obtida (grau alcoólico aparente), anote (Figura 2A);

Importante: o alcoômetro não pode tocar nas paredes nem no fundo da proveta (Figura 2).

c) Verificar a temperatura com o termômetro. Anotar (Figura 2B);

d)Projetar na tabela dos líquidos espirituosos (Anexo 1) os valores de grau aparente $\left(2^{\circ}\right.$ passo) e temperatura ( $3^{\circ}$ passo). O grau alcoólico real do álcool estará onde os dados se cruzam;

e) Calcular o volume que será utilizado de álcool pela Equação 2 (BRASIL, 2012).

Exemplo: $90^{\circ} \mathrm{GL}$ (aparente) e 20 graus, na tabela de líquidos espirituosos corresponde a 88,7 ${ }^{\circ} \mathrm{GL}$.

$$
\mathrm{C} 1 \times \mathrm{V} 1=\mathrm{C} 2 \times \mathrm{V} 2
$$

Onde:

C1: grau alcoólico real (da tabela de líquidos espirituosos);

V1: X mL (volume que será utilizado de álcool);

C2: grau alcoólico que se deseja obter $\left(77^{\circ} \mathrm{GL}\right)$;

V2: volume que álcool que se deseja preparar (Ex. $1000 \mathrm{~mL})$.

Ao aplicar-se o exemplo acima na equação 2:

$\mathrm{C} 1=88,7^{\circ} \mathrm{GL}$

$\mathrm{V} 1=\mathrm{X} \mathrm{mL}$

$\mathrm{C} 2=77^{\circ} \mathrm{GL}$

$\mathrm{V} 2=1000 \mathrm{~mL}$

$\mathrm{C} 1 \times \mathrm{V} 1=\mathrm{C} 2 \times \mathrm{V} 2$

$\left.1^{\circ}\right) 88,7 \times X=77 \times 1000$

$\left.2^{\circ}\right) 88,7 \mathrm{X}=77000$

$\left.3^{\circ}\right) \mathrm{X}=77000 / 88,7$

$\left.4^{\circ}\right) \mathrm{X}=868,09 \mathrm{~mL}$ de álcool etílico

Vale:

f) Medir o volume de álcool calculado (do exemplo $=868,09 \mathrm{~mL}$ ) e completar para $1000 \mathrm{ml}$ com água purificada (destilada ou deionizada).

g) Colocar o alcoômetro na solução preparada para conferir o grau alcoólico real, utilizando a tabela dos líquidos espirituosos (Anexo 1). O grau alcoólico não deverá ser menor que $76,9^{\circ} \mathrm{GL}$ e não mais que $81,4^{\circ} \mathrm{GL}$ (BRASIL, 2012). É preciso proceder o controle de qualidade conforme descrito no item 3 deste manual. 
Figura 2 - Aferição do grau real utilizando alcoômetro (A) e aferição da temperatura do álcool etílico (B)

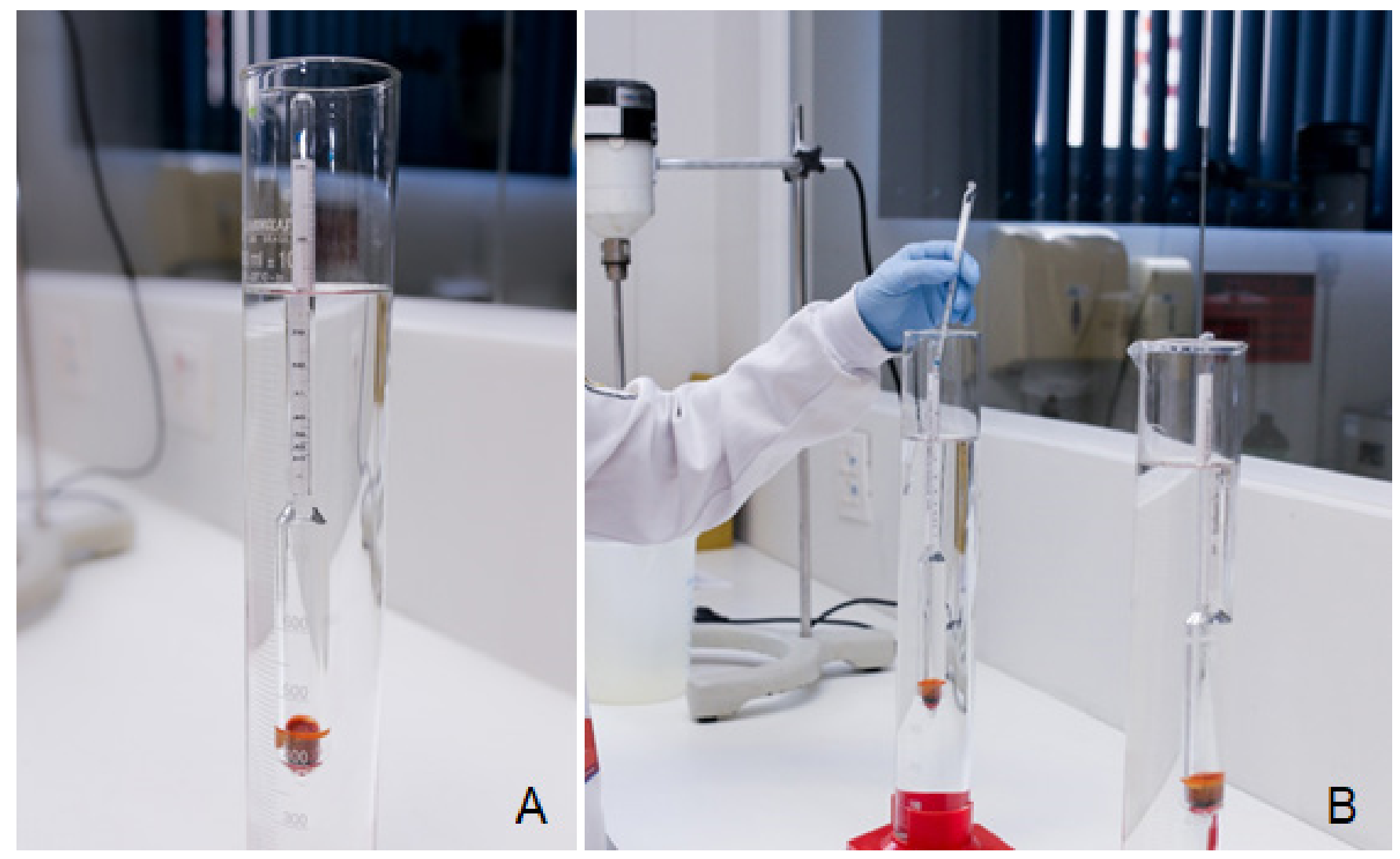

Fonte: as autoras. 


\section{PREPARAÇÃO DE ÁLCOOL GEL}

\section{Material Necessário:}

$\checkmark$ Béquer de vidro;

$\checkmark$ Peneira ou tamis;

$\checkmark$ Espátula de alumínio;

$\checkmark$ Espátula de plástico;

$\checkmark$ Pipeta Pasteur;

$\checkmark$ pHmetro ou fitas indicadoras de $\mathrm{pH}$;

$\checkmark$ Balança analítica;

$\checkmark$ Agitador mecânico ou mixer.

$\checkmark$ EPIs: luvas, máscara, jaleco de manga longa, calçado fechado.

\section{Formulação:}

Carbopol 940 pó ------ 0,5\%

Glicerina ---------- 5,0\%

Álcool a 70\% (p/p)------ *q.s.p. 100\%

*quantidade suficiente para.

\section{Modo de Preparo:}

a) Pesar o carbopol e passar na peneira ou em um tamis (Figura 3A).

b) Verter o pó sobre o álcool 70\% (p/p). Dispersar até desfazer os grumos. Colocar no agitador mecânico se necessário (Figura 3B). Deixar "over night" em recipiente bem fechado.

c) No dia seguinte, utilizar agitador mecânico ou mixer para completa homogeneização do carbopol hidratado no álcool 70\% (p/p).

d) Acrescentar a glicerina e homogeneizar. Se optar por acrescentar essência (gotas), este é o passo ideal.

e) Utilizar trietanolamina ou solução de hidróxido de sódio (25\%) para ajuste do $\mathrm{pH}$ (5 a 7) e aumento da viscosidade. A quantidade utilizada de alcalinizante será a quantidade necessária para alcançar o $\mathrm{pH}$ e a viscosidade ideal (Figuras 3C e 3D) (BRASIL, 2012). 
Figura 3 - Pesagem do carbopol (A), carbopol adicionado ao álcool etílico sob agitação mecânica (B), adição de alcalinizante e formação do gel (C) e álcool 70\% (p/p) em gel (D)
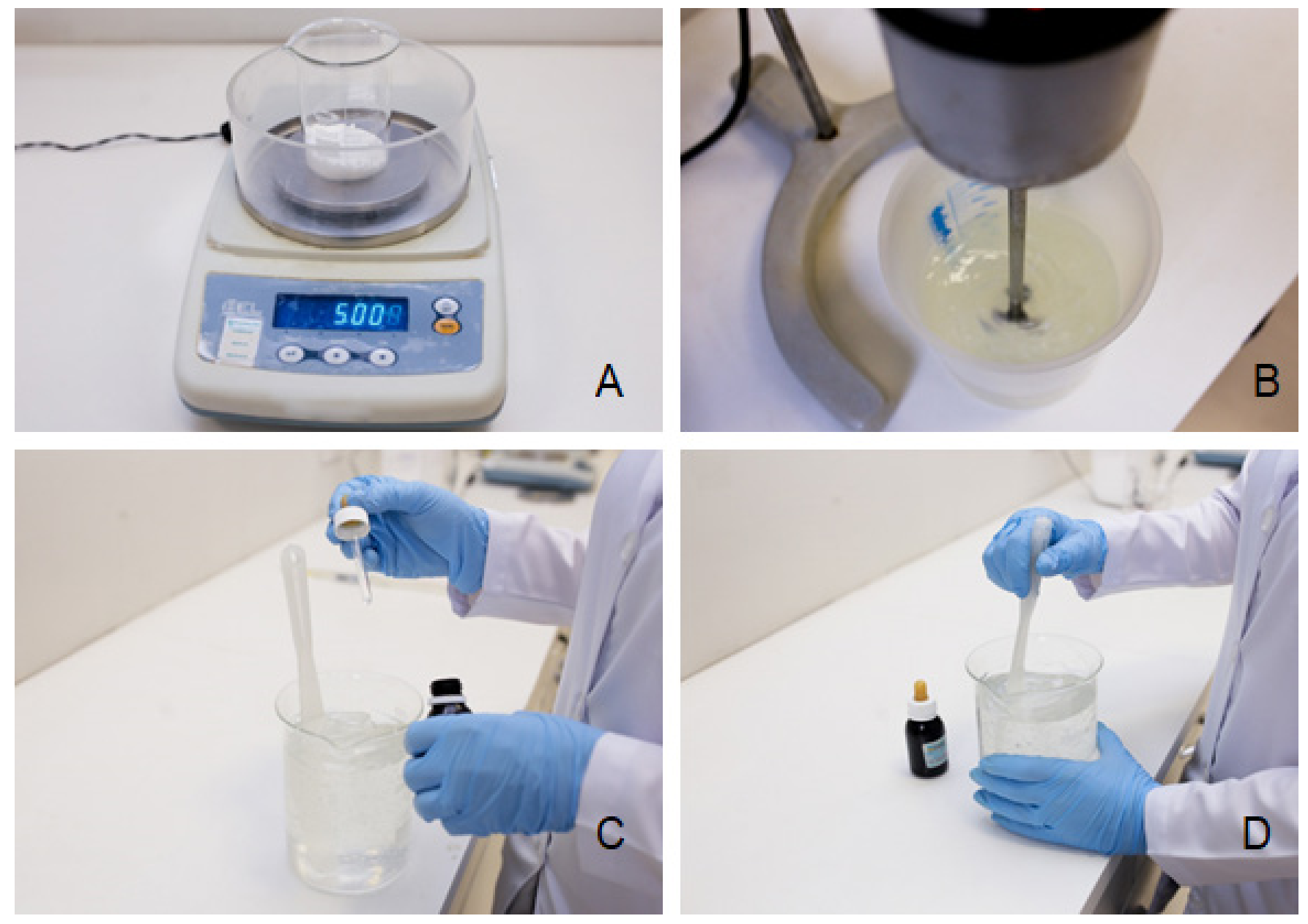

Fonte: as autoras. 


\section{PREPARAÇÃO DE ANTISSÉPTICO PARA MÃOS E SUPERFÍCIES SEGUNDO A ORGANIZAÇÃO MUNDIAL DA SAÚDE (OMS, 2010)}

\section{Material necessário:}

$\checkmark$ Vidrarias: béquer ou outro recipiente compatível com o volume a ser preparado, proveta ou cálice e bastão de vidro para mistura;

$\checkmark$ Frascos com tampa para acondicionamento da solução;

$\checkmark$ Caneta e papel;

$\checkmark$ EPIs: luvas, máscara, óculos de proteção, jaleco de manga longa, calçado fechado.

\section{Formulação 1:}

Etanol 96\%;

Peróxido de hidrogênio 3\%;

Glicerol 98\%;

Água destilada ou água deionizada.

\section{Para preparação de $10 \mathrm{~L}$ :}

Etanol 96\%: $8333 \mathrm{~mL}$;

Peróxido de hidrogênio 3\%: $417 \mathrm{~mL}$;

Glicerol 98\%: $145 \mathrm{~mL}$;

Água: $1105 \mathrm{~mL}$.

\section{Formulação 2:}

Álcool isopropílico 99,8\%;

Peróxido de hidrogênio 3\%*;

Glicerol 98\%;

Água destilada ou água deionizada.

*Além da utilização dos EPIs já citados, é necessária a utilização de óculos de proteção para manusear o peróxido de hidrogênio.

\section{Para preparação de $10 \mathrm{~L}$ :}

Álcool isopropílico 99,8\%: $7515 \mathrm{~mL}$;

Peróxido de hidrogênio 3\%: $417 \mathrm{~mL}$;

Glicerol 98\%: $145 \mathrm{~mL}$;

Água: 1923 mL. 


\section{Modo de Preparo}

a) Medir o álcool e transferir para um recipiente grande;

b) Adicionar o peróxido de hidrogênio medido em proveta ou cálice;

c) Adicionar o glicerol medido em proveta ou cálice. Como o glicerol é muito viscoso e fica aderido à parede da proveta, deve ser lavado com água destilada e vertido no recipiente contendo os outros componentes;

d) Completar para 10 L com água destilada. A solução deve ser misturada agitando-a suavemente;

e) Tampar o recipiente contendo a solução logo que possível após a preparação, para impedir a evaporação;

f) Dividir imediatamente a solução em seus recipientes finais (por ex., 500 ou $100 \mathrm{~mL}$ em recipientes plásticos) e deixar os frascos em repouso por 72 horas antes de usar. Esse tempo permite que esporos presentes no álcool ou nos frascos sejam destruídos.

g) Medir a solução produzida com o alcoômetro. Limite aceitável +/- 5\% da concentração alvo (75\% $85 \%$ para o etanol) (Figura 4) a $25^{\circ} \mathrm{C}(\mathrm{OMS}, 2010)$.

\section{Concentrações finais no produto:}

- Etanol 80\% (v/v) ou álcool isopropílico 75\% (v/v);

- Glicerol 1,45\% (v/v);

- Peróxido de hidrogênio $0,125 \%(\mathrm{v} / \mathrm{v})$.

Figura 4 - Conferência do grau real da solução desinfetante para mãos e superfícies

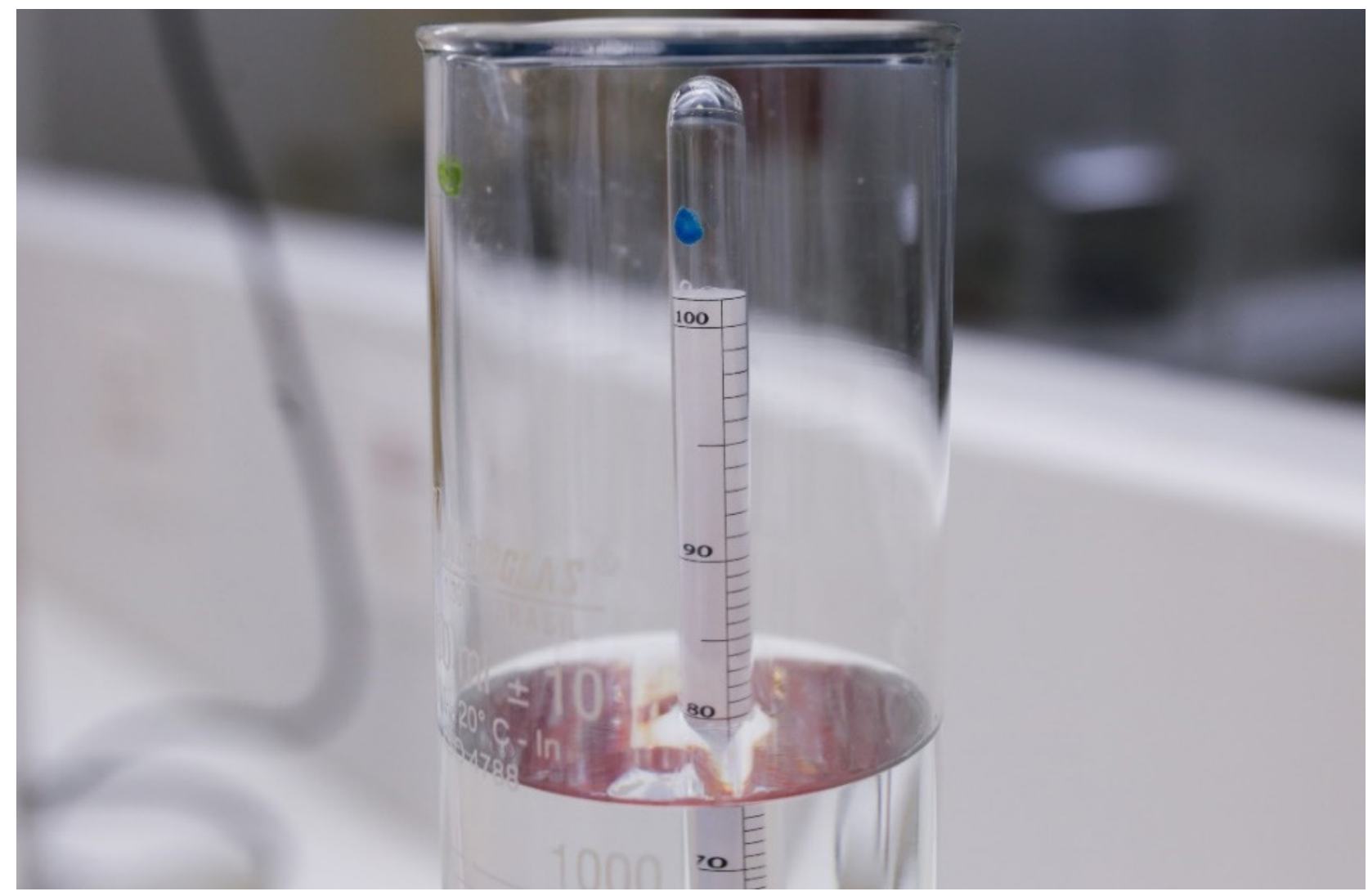

Fonte: as autoras. 


\section{INFORMAÇÕES GERAIS - ROTULAGEM}

As seguintes informações devem estar contidas na rotulagem do produto preparado (Quadro 1):

$\checkmark$ Uso externo exclusivamente/ Exclusivamente/ Somente para uso externo;

$\checkmark$ Evite contato com os olhos;

$\checkmark$ Manter o produto fora do alcance das crianças;

$\checkmark$ Data de produção e número do lote;

$\checkmark$ Validade (recomenda-se usar o produto por no máximo seis meses após a produção);

$\checkmark$ Manter o frasco tampado ao abrigo da luz e do calor;

$\checkmark$ Uso: aplique a quantidade razoável da formulação à base de álcool e cubra todas as superfícies das mãos. Esfregue as mãos até secar para garantir que todas as partes das mãos tenham sido atingidas pelo produto.

$\checkmark$ Composição (a depender da formulação):

- Álcool 70\% m/m líquido: álcool etílico e água;

- Álcool $77^{\circ} \mathrm{GL}$ v/v líquido: álcool etílico e água;

- Álcool Gel: álcool etílico, água, carbopol 940, glicerina e essência (opcional);

- Desinfetante para mãos e superfícies segundo a OMS: etanol ou isopropanol, glicerol, peróxido de hidrogênio e água.

- Inflamável: mantenha longe de chamas e calor.

$\checkmark$ Responsável técnico com no do registro no órgão competente (conselho profissional).

$\checkmark$ Nome, endereço, contato e dados da empresa fabricante.

Quadro 1 - Modelo de rótulo para álcool gel

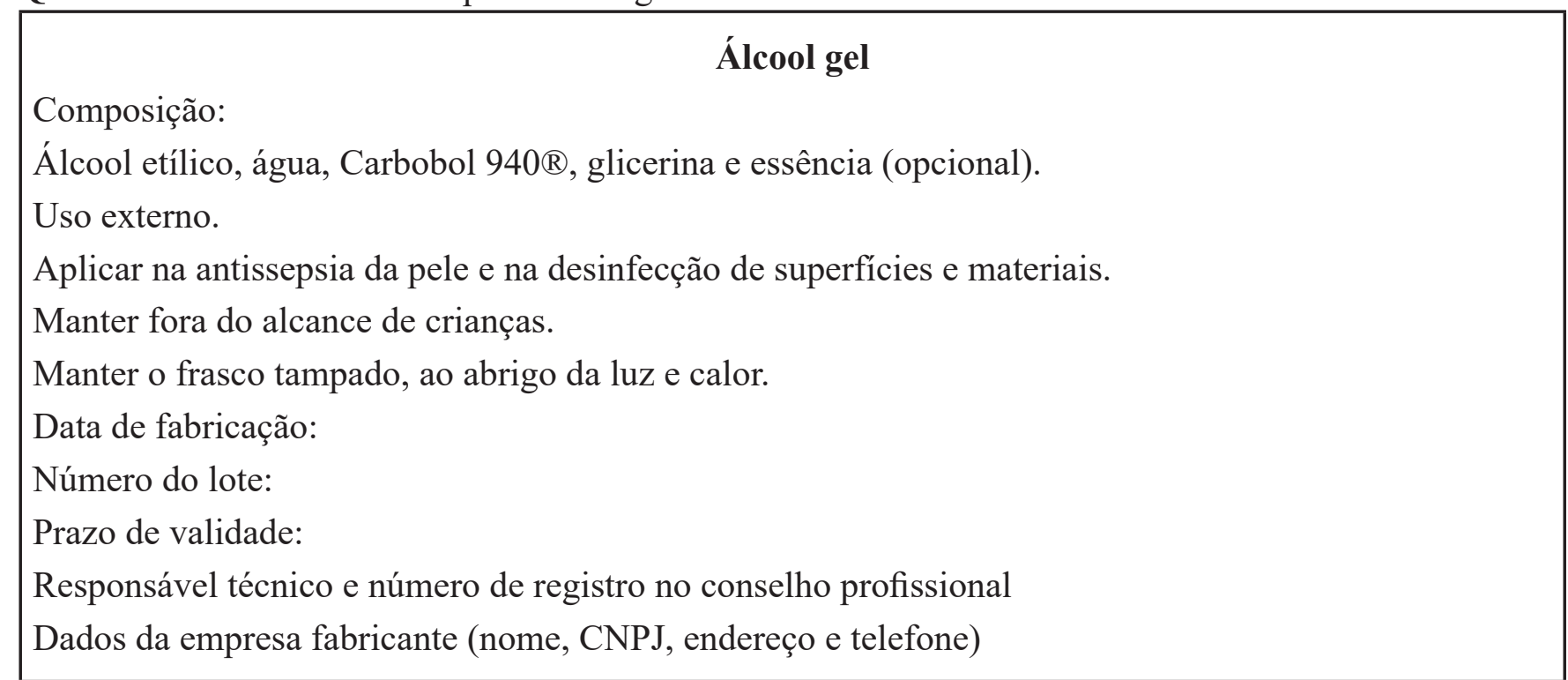

Fonte: as autoras. 


\section{REFERÊNCIAS}

AGÊNCIA NACIONAL DE VIGILÂNCIA SANITÁRIA. Segurança do paciente em serviços de saúde: limpeza e desinfecção de superfícies. Brasília: Anvisa, 2012.

ARAÚJO, L. F.; MELO, T. N. L; FORTUNA, J. L. Avaliação da Eficácia do Álcool Comercial para Desinfecção de Superfícies. Revista Científica do ITPAC, v.12, n.2, pub.7, p. 66-71, 2019.

BARBOSA, A. S. A. A. et al. Eficácia do álcool etílico e quaternário de amônio na desinfecção de equipamentos médicos hospitalares. Revista de Epidemiologia e Controle de Infecções, v.8, n. 4, p. 409-414, 2018.

BERNARDI, G. A.; COSTA, T. C. M. Avaliação da atividade antimicrobiana do álcool 70\% em superfícies contaminadas. Journal of Infection Control, v. 6, n. 4, p. 1-11, 2017.

BRASIL. Agência Nacional de Vigilância Sanitária (ANVISA). Segurança do Paciente em Serviços de Saúde: Limpeza e Desinfecção de Superfícies. Brasília, [s.n.], p.116, 2010.

BRASIL, Ministério da Saúde, Agência Nacional de Vigilância Sanitária (ANVISA). Farmacopeia Brasileira, v. 1 e 2, 6. ed. Brasília, 2019. Disponível em: http://portal.anvisa.gov.br/farmacopeia-brasileira

BRASIL, Ministério da Saúde, Agência Nacional de Vigilância Sanitária (ANVISA). Formulário nacional da farmacopeia brasileira, $2^{\circ}$ edição, Brasília, 2012.

BRASIL. RDC N 67, de 8 de outubro de 2007. Dispõe sobre Boas Práticas de Manipulação de Preparações Magistrais e Oficinais para Uso Humano em farmácias, 2007.

GRAZIANO, M. U. et al. Eficácia da desinfecção com álcool 70\% (p/v) de superfícies contaminadas sem limpeza prévia. Revista Latino-Americana de. Enfermagem, v. 21, n. 2, 2013.

KALIL E. M.; COSTA, A. J.F. Desinfecção e esterilização. Acta Ortopédica Brasileira, v. 2, n. 4, p.1-4, 1994.

MORIYA T.; MÓDENA J.L.P., Assepsia e Antissepsia: Técnicas de Esterilização. In: SIMPÓSIO: FUNDAMENTOS EM CLÍNICA CIRÚRGICA - 1ª Parte, v. 41, n. 3, p. 265-73, Ribeirão Preto, 2008.

PARANÁ. Secretaria de Estado da Educação do Paraná (SEEP). Álcool gel deve ter registro e não é indicado para a limpeza de superfícies. Redescola. Curitiba-PR. 24 de agosto de 2009. http://www. mrherondomingues.seed.pr.gov.br/modules/noticias/ Disponível em: Acesso em 17 de novembro de 2020.

PSALTIKIDIS, E. M.; SILVA, A.; GRAZIANO, K. U. Enfermagem em Centro de Material e esterilização. São Paulo: Manole, 2011.

TORTORA, J.; CASE, FUNKE, R. Microbiologia. 12. ed. Porto Alegre: Artmed. 2017. 
WORLD HEALTH ORGANIZATION. Guide to Local Production: WHO - recommended Handrub Formulations. OMS, 2010. Acesso em 14 de agosto de 2020.

WORLD HEALTH ORGANIZATION. Coronavirus disease 2019 (COVID-19). Disponível em: https:// ais.paho.org/phip/viz/COVID19Table.asp Acesso em 14 de agosto de 2020. 
Anexo 1 - Força real dos Líquidos Espirituosos

\begin{tabular}{|c|c|c|c|c|c|c|c|c|c|c|c|c|c|c|c|}
\hline Temp ${ }^{\circ} \mathrm{C}$ & $56 \mathrm{c}$ & $57 \mathrm{c}$ & $58 \mathrm{c}$ & $59 \mathrm{c}$ & $60 \mathrm{c}$ & $61 \mathrm{c}$ & $62 \mathrm{c}$ & $63 \mathrm{c}$ & $64 \mathrm{c}$ & $65 \mathrm{c}$ & $66 \mathrm{c}$ & $67 \mathrm{c}$ & $68 \mathrm{c}$ & $69 \mathrm{c}$ & $70 \mathrm{c}$ \\
\hline $30^{\circ}$ & 50,6 & 51,6 & 52,6 & 53,6 & 54,7 & 55,7 & 56,7 & 57,8 & 58,8 & 59,9 & 60,9 & 61,9 & 63,0 & 64,0 & 65,0 \\
\hline $29^{\circ}$ & 51,0 & 52,0 & 53,0 & 54,0 & 55,0 & 56,0 & 57,1 & 58,1 & 59,2 & 60,2 & 61,2 & 62,3 & 63,3 & 64,3 & 65,4 \\
\hline $28^{\circ}$ & 51,3 & 52,3 & 53,3 & 54,4 & 55,4 & 56,4 & 57,5 & 58,5 & 59,5 & 60,6 & 61,6 & 62,6 & 63,7 & 64,7 & 65,7 \\
\hline $27^{\circ}$ & 51,7 & 52,7 & 53,7 & 54,8 & 55,8 & 56,8 & 57,8 & 58,9 & 59,9 & 60,9 & 61,9 & 63,0 & 64,0 & 65,0 & 66,0 \\
\hline $26^{\circ}$ & 52,0 & 53,0 & 54,0 & 55,1 & 56,1 & 57,1 & 58,1 & 59,2 & 60,2 & 61,3 & 62,3 & 63,3 & 64,3 & 65,3 & 66,4 \\
\hline $25^{\circ}$ & 52,4 & 53,4 & 54,4 & 55,5 & 56,5 & 57,5 & 58,5 & 59,5 & 60,6 & 61,6 & 62,6 & 63,7 & 64,7 & 65,7 & 66,7 \\
\hline $24^{\circ}$ & 52,8 & 53,8 & 54,8 & 55,8 & 56,8 & 57,8 & 58,9 & 59,9 & 61,0 & 62,0 & 63,0 & 64,0 & 65,0 & 66,0 & 67,1 \\
\hline $23^{\circ}$ & 53,1 & 54,1 & 55,1 & 56,1 & 57,1 & 58,1 & 59,2 & 60,2 & 61,3 & 62,3 & 63,3 & 64,3 & 65,4 & 66,4 & 67,4 \\
\hline $22^{\circ}$ & 53,5 & 54,5 & 55,5 & 56,5 & 57,5 & 58,5 & 59,5 & 60,6 & 61,6 & 62,7 & 63,7 & 64,7 & 65,7 & 66,7 & 67,8 \\
\hline $21^{\circ}$ & 53,9 & 54,9 & 55,9 & 56,9 & 57,9 & 58,9 & 59,9 & 61,0 & 62,0 & 63,0 & 64,0 & 65,0 & 66,0 & 67,0 & 68,1 \\
\hline $20^{\circ}$ & 54,2 & 55,2 & 56,2 & 57,2 & 58,2 & 59,2 & 60,3 & 61,3 & 62,3 & 63,3 & 64,3 & 65,4 & 66,4 & 67,4 & 68,4 \\
\hline $19^{\circ}$ & 54,6 & 55,6 & 56,6 & 57,6 & 58,6 & 59,6 & 60,6 & 61,6 & 62,7 & 63,7 & 64,7 & 65,7 & 66,7 & 67,7 & 68,7 \\
\hline $18^{\circ}$ & 54,9 & 55,9 & 56,9 & 57,9 & 58,9 & 59,9 & 61,0 & 62,0 & 63,0 & 64,0 & 65,0 & 66,0 & 67,0 & 68,0 & 69,0 \\
\hline $17^{\circ}$ & 55,3 & 56,3 & 57,3 & 58,3 & 59,3 & 60,3 & 61,3 & 62,2 & 63,3 & 64,3 & 65,3 & 66,3 & 67,3 & 68,3 & 69,3 \\
\hline $16^{\circ}$ & 55,6 & 56,6 & 57,6 & 58,6 & 59,6 & 60,6 & 61,7 & 62,7 & 63,7 & 64,7 & 65,7 & 66,7 & 67,7 & 68,7 & 69,7 \\
\hline $15^{\circ}$ & 56,0 & 57,0 & 58,0 & 59,0 & 60,0 & 61,0 & 62,0 & 63,0 & 64,0 & 65,0 & 66,0 & 67,0 & 68,0 & 69,0 & 70,0 \\
\hline $14^{\circ}$ & 56,3 & 57,3 & 58,3 & 59,3 & 60,3 & 61,3 & 62,3 & 63,3 & 64,3 & 65,3 & 66,3 & 67,3 & 68,3 & \begin{tabular}{|l|l|}
69,3 \\
\end{tabular} & 70,3 \\
\hline $13^{\circ}$ & 56,7 & 57,7 & 58,7 & 59,7 & 60,7 & 61,7 & 62,7 & 63,7 & 64,7 & 65,7 & 66,7 & 67,7 & 68,7 & 69,6 & 70,6 \\
\hline $12^{\circ}$ & 57,0 & 58,0 & 59,0 & 60,0 & 61,0 & 62,0 & 63,0 & 64,0 & 65,0 & 66,0 & 67,0 & 68,0 & 69,0 & 70,0 & 71,0 \\
\hline $11^{\circ}$ & 57,4 & 58,4 & 59,4 & 60,4 & 61,4 & 62,4 & 63,4 & 64,4 & 65,4 & \begin{tabular}{|l|l|}
66,4 \\
\end{tabular} & 67,3 & 68,3 & 69,3 & \begin{tabular}{|l|l|}
70,3 \\
\end{tabular} & 71,3 \\
\hline \multirow[t]{2}{*}{$10^{\circ}$} & 57,8 & 58,8 & 59,7 & 60,7 & 61,7 & 62,7 & 63,7 & 64,7 & 65,7 & 66,7 & 67,6 & 68,6 & 69,6 & 70,6 & 71,6 \\
\hline & $71 \mathrm{c}$ & $72 \mathrm{c}$ & $73 c$ & $74 \mathrm{c}$ & $75 \mathrm{c}$ & $76 c$ & $77 \mathrm{e}$ & $78 \mathrm{c}$ & $79 \mathrm{c}$ & $80 \mathrm{c}$ & $81 \mathrm{c}$ & $82 \mathrm{c}$ & $83 c$ & $84 \mathrm{c}$ & $85 \mathrm{c}$ \\
\hline $30^{\circ}$ & 66,1 & 67,1 & 68,2 & 69,2 & 70,3 & 71,3 & 72,3 & 73,3 & 74,4 & 75,4 & 76,4 & 77,5 & 78,6 & 79,6 & 80,6 \\
\hline $29^{\circ}$ & 66,4 & 67,4 & 68,5 & 69,5 & 70,6 & 71,6 & 72,6 & 73,7 & 74,7 & 75,7 & 76,7 & 77,8 & 78,9 & \begin{tabular}{|l|}
79,9 \\
\end{tabular} & 80,9 \\
\hline $28^{\circ}$ & 66,8 & 67,8 & 68,8 & 69,9 & 70,9 & 71,9 & 73,0 & 74,0 & 75,0 & 76,0 & 77,1 & 78,1 & 79,2 & 80,2 & 81,2 \\
\hline $27^{\circ}$ & 67,1 & 68,1 & 69,2 & 70,2 & 71,2 & 72,2 & 73,3 & 74,3 & 75,3 & 76,3 & 77,4 & 78,4 & 79,5 & 80,5 & 81,5 \\
\hline $26^{\circ}$ & 67,4 & 68,4 & 69,5 & 70,5 & 71,5 & 72,5 & 73,6 & 74,6 & 75,6 & 76,7 & 77,7 & 78,7 & 79,8 & 80,8 & 81,8 \\
\hline $25^{\circ}$ & 67,8 & 68,8 & 69,8 & 70,8 & 71,8 & 72,8 & 73,9 & 74,9 & 76,0 & 77,0 & 78,0 & 79,0 & 80,1 & 81,1 & 82,1 \\
\hline $24^{\circ}$ & 68,1 & 69,1 & 70,1 & 71,2 & 72,2 & 73,2 & 74,2 & 75,5 & 76,6 & 77,6 & 78,6 & 79,6 & 80,7 & 81,7 & \begin{tabular}{|l|l}
82,7 \\
\end{tabular} \\
\hline $23^{\circ}$ & 68,4 & 69,4 & 70,5 & 71,5 & 72,5 & 73,5 & 74,5 & 75,2 & 76,3 & 77,3 & 78,3 & 79,3 & 80,4 & 81,4 & 82,4 \\
\hline $22^{\circ}$ & 68,8 & 69,8 & 70,8 & 71,8 & 72,8 & 73,8 & 74,8 & 75,9 & 76,9 & 77,9 & 78,9 & 79,9 & 81,0 & 82,0 & 83,0 \\
\hline $21^{\circ}$ & 69,1 & 70,1 & 71,1 & 72,1 & 73,1 & 74,1 & 75,2 & 76,2 & 77,2 & 78,2 & 79,2 & 80,2 & 81,3 & 82,3 & 83,3 \\
\hline $20^{\circ}$ & 69,4 & 70,4 & 71,4 & 72,4 & 73,4 & 74,4 & 75,5 & 76,5 & 77,5 & 78,5 & 79,5 & 80,5 & 81,6 & 82,6 & 83,6 \\
\hline $19^{\circ}$ & 69,7 & 70,7 & 71,7 & 72,7 & 73,7 & 74,7 & 75,8 & 76,8 & 77,8 & 78,8 & 79,8 & 80,8 & 81,9 & 82,9 & \begin{tabular}{|l|}
83,9 \\
\end{tabular} \\
\hline $18^{\circ}$ & 70,0 & 71,0 & 72,0 & 73,0 & 74,0 & 75,1 & 76,1 & 77,1 & 78,1 & 79,1 & 80,1 & 81,1 & 82,1 & 83,1 & 84,1 \\
\hline $17^{\circ}$ & 70,3 & 71,3 & 72,3 & 73,3 & 74,3 & 75,4 & 76,4 & 77,4 & 78,4 & 79,4 & 80,4 & 81,4 & 82,4 & 83,4 & 84,4 \\
\hline $16^{\circ}$ & 70,7 & 71,7 & 72,7 & 73,7 & 74,7 & 75,7 & 76,7 & 77,7 & 78,7 & 79,7 & 80,7 & 81,7 & 82,7 & 83,7 & \begin{tabular}{|l|l}
84,7 \\
\end{tabular} \\
\hline $15^{\circ}$ & 71,0 & 72,0 & 73,0 & 74,0 & 75,0 & 76,0 & 77,0 & 78,0 & 79,0 & 80,0 & 81,0 & 82,0 & 83,0 & 84,0 & 85 \\
\hline $14^{\circ}$ & 71,3 & 72,3 & 73,3 & 74,3 & 75,3 & 76,3 & 77,3 & 78,3 & 79,3 & 80,3 & 81,3 & 82,3 & 83,3 & 84,3 & 85,3 \\
\hline $13^{\circ}$ & 71,6 & 72,6 & 73,6 & 74,6 & 75,6 & 76,6 & 77,6 & 78,6 & 79,6 & 80,6 & 81,6 & 82,6 & 83,6 & 84,6 & 85,5 \\
\hline $12^{\circ}$ & 72,0 & 72,9 & 73,9 & 74,9 & 75,9 & 76,9 & 77,9 & 78,9 & 79,9 & 80,9 & 81,9 & 82,9 & 83,9 & 84,8 & 85,8 \\
\hline $11^{\circ}$ & 72,3 & 73,2 & 74,2 & 75,2 & 76,2 & 77,2 & 78,2 & 79,2 & 80,2 & 81,2 & 82,2 & 83,1 & 84,1 & 85,1 & 86,1 \\
\hline \multirow[t]{2}{*}{$10^{\circ}$} & 72,6 & 73,5 & 74,5 & 75,5 & 76,5 & 77,5 & 78,5 & 79,5 & 80,5 & 81,5 & 82,4 & 83,4 & 84,4 & 85,4 & 86,4 \\
\hline & $86 \mathrm{c}$ & $87 \mathrm{c}$ & $88 \mathrm{c}$ & $89 \mathrm{c}$ & $90 \mathrm{c}$ & $91 \mathrm{c}$ & $92 \mathrm{c}$ & $93 \mathrm{c}$ & $94 \mathrm{c}$ & $95 \mathrm{c}$ & $96 \mathrm{c}$ & $97 \mathrm{c}$ & $98 \mathrm{c}$ & $99 \mathrm{c}$ & $100 \mathrm{c}$ \\
\hline $30^{\circ}$ & 81,7 & 82,7 & 83,8 & 84,9 & 86 & 87,1 & 88,2 & 89,3 & 90,4 & 91,5 & 92,7 & 93,8 & 95 & 96,1 & 97,7 \\
\hline $29^{\circ}$ & 82 & 83 & 84,1 & 85,1 & 86,2 & 87,3 & 88,4 & 89,5 & 90,6 & 91,7 & 92,9 & 94,1 & 95,2 & 96,3 & 97,5 \\
\hline $28^{\circ}$ & 82,3 & 83,3 & 84,4 & 85,4 & 86,5 & 87,6 & 88,7 & 89,8 & 90,9 & 92 & 93,2 & 94,3 & 95,4 & 96,5 & 97,7 \\
\hline $27^{\circ}$ & 82,6 & 83,6 & 84,7 & 85,7 & 86,7 & 87,9 & 89 & 90,1 & 91,1 & 92,2 & 9,4 & 94,5 & 95,6 & \begin{tabular}{|l}
96,7 \\
\end{tabular} & 97,9 \\
\hline $26^{\circ}$ & 82,9 & 83,9 & 84,9 & 86 & 87,1 & 88,2 & 89,2 & 90,3 & 91,4 & 92,5 & 93,6 & 94,7 & 95,8 & 96,9 & 98,1 \\
\hline $25^{\circ}$ & 83,2 & 84,3 & 85,2 & 86,3 & 87,4 & 88,4 & 89,5 & 90,6 & 91,6 & 92,7 & 93,8 & 94,9 & 96 & 97,1 & 98,2 \\
\hline $24^{\circ}$ & 83,5 & 84,5 & 85,5 & 86,5 & 87,6 & 88,7 & 89,7 & 90,8 & 91,9 & 93 & 94,1 & 95,2 & 96,2 & 97,3 & 98,4 \\
\hline $23^{\circ}$ & 83,8 & 84,8 & 85,8 & 86,8 & 87,9 & 89 & 90 & 91,1 & 92,1 & 93,2 & 94,3 & 95,4 & 96,5 & 97,5 & 98,6 \\
\hline $22^{\circ}$ & 84 & 85 & 86,1 & 87,1 & 88,2 & 89,2 & 90,2 & 91,3 & 92,4 & 93,4 & 94,5 & 95,6 & 96,7 & 97,7 & 98,8 \\
\hline $21^{\circ}$ & 84,3 & 85,3 & 86,4 & 87,4 & 88,4 & 89,5 & 90,5 & 91,6 & 92,6 & 93,7 & 94,7 & 95,8 & 96,9 & 97,9 & 99 \\
\hline $20^{\circ}$ & 84,6 & 85,6 & 86,6 & 87,7 & 88,7 & 89,7 & 90,8 & 91,8 & 92,9 & 93,9 & 95 & 96 & 97,1 & \begin{tabular}{|c|}
98,1 \\
\end{tabular} & 99,1 \\
\hline $19^{\circ}$ & 84,9 & 85,9 & 86,9 & 87,9 & 88,9 & 90 & 91,1 & 92,1 & 93,1 & 94,1 & 95,2 & 96,2 & 97,3 & 98,3 & 99,3 \\
\hline $18^{\circ}$ & 85,2 & 86,2 & 87,2 & 88,2 & 89,2 & 90,2 & 91,3 & 92,3 & 93,3 & 94,3 & 95,4 & 96,4 & 97,4 & \begin{tabular}{|l|l}
98,5 \\
\end{tabular} & 99,5 \\
\hline $17^{\circ}$ & 85,4 & 86,4 & 87,4 & 88,4 & 89,5 & 90,5 & 91,5 & 92,6 & 93,6 & 94,6 & 95,6 & 96,6 & 97,6 & 98,7 & 99,7 \\
\hline $16^{\circ}$ & 85,7 & 86,7 & 87,7 & 88,7 & 89,7 & 90,8 & 91,8 & \begin{tabular}{|l|l|}
92,8 \\
\end{tabular} & 93,8 & \begin{tabular}{|l|l}
94,8 \\
\end{tabular} & \begin{tabular}{|c|}
95,8 \\
\end{tabular} & 96,7 & 97,8 & \begin{tabular}{|l}
98,8 \\
\end{tabular} & 99,8 \\
\hline $15^{\circ}$ & 86 & 87 & 88 & 89 & 90 & 91 & 92 & 93 & 94 & 95 & 96 & 97 & 98 & 99 & 100 \\
\hline $14^{\circ}$ & 86,3 & 87,3 & 88,2 & 89,2 & 90,2 & 91,2 & 92,2 & 93,2 & 94,2 & 95,2 & 96,2 & 97,2 & 98,2 & 99,2 & \\
\hline $13^{\circ}$ & 86,5 & 87,5 & 88,5 & 89,5 & 90,5 & 91,5 & 92,5 & 93,5 & 94,4 & 95,4 & 96,4 & 97,4 & 98,4 & 99,3 & \\
\hline $12^{\circ}$ & 86,8 & 87,8 & 88,7 & 89,7 & 90,7 & 91,7 & 92,7 & 97,7 & 94,7 & 95,6 & 96,6 & 97,6 & 98,5 & 99,5 & \\
\hline $11^{\circ}$ & 87,1 & 88 & 89 & 90 & 91 & 92 & 92,9 & 93,9 & 94,9 & 95,8 & 96,8 & 97,8 & 98,7 & 99,7 & \\
\hline $10^{\circ}$ & 87,4 & 88,3 & 89,3 & 90,2 & 91,2 & 92,2 & 93,2 & 94,2 & 95,1 & 95 & 97 & 98 & 95,9 & 99,9 & \\
\hline
\end{tabular}

Fonte: Adaptado de ANVISA, 2012. 
Anexo 2 - Tabela alcoométrica

\begin{tabular}{|c|c|c|c|c|c|}
\hline $\begin{array}{l}\text { Grau centesimal, ou } \\
\text { centésimos de álcool } \\
\text { absoluto em volume }\end{array}$ & $\begin{array}{c}\text { Densidade a } 15^{\circ} \mathrm{C} \\
\text { da mistura de água e } \\
\text { álcool absoluto }\end{array}$ & $\begin{array}{l}\text { Título ponderal ou } \\
\text { centésimos de álcool } \\
\text { absoluto em peso }\end{array}$ & $\begin{array}{l}\text { Grau centesimal, ou } \\
\text { centésimos de álcool } \\
\text { absoluto em volume }\end{array}$ & $\begin{array}{l}\text { Densidade a } 15^{\circ} \mathrm{C} \\
\text { da mistura de água e } \\
\text { álcool absoluto }\end{array}$ & $\begin{array}{l}\text { Título ponderal ou } \\
\text { centésimos de álcool } \\
\text { absoluto em peso }\end{array}$ \\
\hline $100 \mathrm{C}$ & 0,79433 & 100,000 & $50 \mathrm{C}$ & 0,93437 & 42,506 \\
\hline $99 \mathrm{C}$ & 0,79926 & 98,389 & $49 \mathrm{C}$ & 0,93629 & 41,571 \\
\hline $98 \mathrm{C}$ & 0,80390 & 96,833 & $48 \mathrm{C}$ & 0,93817 & 40,641 \\
\hline $97 \mathrm{C}$ & 0,80829 & 95,324 & $47 \mathrm{C}$ & 0,94002 & 39,716 \\
\hline $96 \mathrm{C}$ & 0,81246 & 93,859 & $46 \mathrm{C}$ & 0,94183 & 38,796 \\
\hline $95 \mathrm{C}$ & 0,81641 & 92,430 & $45 \mathrm{C}$ & 0,94361 & 37,881 \\
\hline $94 \mathrm{C}$ & 0,82020 & 91,035 & $44 \mathrm{C}$ & 0,94535 & 36,905 \\
\hline $93 \mathrm{C}$ & 0,82385 & 89,666 & $43 \mathrm{C}$ & 0,94705 & 36,066 \\
\hline $92 \mathrm{C}$ & 0,82738 & 88,325 & $42 \mathrm{C}$ & 0,94872 & 35,165 \\
\hline $91 \mathrm{C}$ & 0,83081 & 87,004 & $41 \mathrm{C}$ & 0,95036 & 34,269 \\
\hline $90 \mathrm{C}$ & 0,83415 & 85,703 & $40 \mathrm{C}$ & 0,95196 & 33,377 \\
\hline $89 \mathrm{C}$ & 0,83741 & 84,421 & $39 \mathrm{C}$ & 0,95350 & 32,490 \\
\hline $88 \mathrm{C}$ & 0,84060 & 83,156 & $38 \mathrm{C}$ & 0,95499 & 31,607 \\
\hline $87 \mathrm{C}$ & 0,84372 & 81,907 & $37 \mathrm{C}$ & 0,95645 & 30,728 \\
\hline $86 \mathrm{C}$ & 0,84678 & 80,673 & $36 \mathrm{C}$ & 0,95786 & 29,854 \\
\hline $85 \mathrm{C}$ & 0,84979 & 79,452 & $35 \mathrm{C}$ & 0,95923 & 28,983 \\
\hline $84 \mathrm{C}$ & 0,85275 & 78,245 & $34 \mathrm{C}$ & 0,95055 & 28,116 \\
\hline $83 \mathrm{C}$ & 0,85567 & 77,050 & $33 \mathrm{C}$ & 0,96183 & 27,253 \\
\hline $82 \mathrm{C}$ & 0,85854 & 75,867 & $32 \mathrm{C}$ & 0,96307 & 26,393 \\
\hline $81 \mathrm{C}$ & 0,86137 & 74,696 & $31 \mathrm{C}$ & 0,96428 & 25,536 \\
\hline $80 \mathrm{C}$ & 0,86416 & 73,535 & $30 \mathrm{C}$ & 0,96545 & 24,683 \\
\hline $79 \mathrm{C}$ & 0,86692 & 72,385 & $29 \mathrm{C}$ & 0,96659 & 23,832 \\
\hline $78 \mathrm{C}$ & 0,86965 & 71,244 & $28 \mathrm{C}$ & 0,96769 & 22,984 \\
\hline $77 \mathrm{C}$ & 0,87234 & 70,114 & $27 \mathrm{C}$ & 0,96876 & 22,138 \\
\hline $76 \mathrm{C}$ & 0,87500 & 68,993 & $26 \mathrm{C}$ & 0,96981 & 21,295 \\
\hline $75 \mathrm{C}$ & 0,87763 & 67,881 & $25 \mathrm{C}$ & 0,97084 & 20,455 \\
\hline $74 \mathrm{C}$ & 0,88022 & 66,779 & $24 \mathrm{C}$ & 0,97185 & 19,616 \\
\hline $73 \mathrm{C}$ & 0,88278 & 65,686 & $23 \mathrm{C}$ & 0,97286 & 18,779 \\
\hline $72 \mathrm{C}$ & 0,88531 & 64,601 & $22 \mathrm{C}$ & 0,97387 & 17,944 \\
\hline $71 \mathrm{C}$ & 0,88781 & 63,524 & $21 \mathrm{C}$ & 0,97487 & 17,111 \\
\hline $70 \mathrm{C}$ & 0,89029 & 62,455 & $20 \mathrm{C}$ & 0,97587 & 16,279 \\
\hline $69 \mathrm{C}$ & 0,89274 & 61,394 & $19 \mathrm{C}$ & 0,97688 & 15,449 \\
\hline $68 \mathrm{C}$ & 0,89516 & 60,340 & $18 \mathrm{C}$ & 0,97790 & 14,621 \\
\hline $67 \mathrm{C}$ & 0,89755 & 59,295 & $17 \mathrm{C}$ & 0,97892 & 13,794 \\
\hline $66 \mathrm{C}$ & 0,89991 & 58,257 & $16 \mathrm{C}$ & 0,97995 & 12,969 \\
\hline $65 \mathrm{C}$ & 0,90224 & 57,226 & $15 \mathrm{C}$ & 0,98100 & 12,145 \\
\hline $64 \mathrm{C}$ & 0,90454 & 56,202 & $14 \mathrm{C}$ & 0,98206 & 11,324 \\
\hline $63 \mathrm{C}$ & 0,90682 & 55,185 & $13 \mathrm{C}$ & 0,98314 & 10,503 \\
\hline $62 \mathrm{C}$ & 0,90907 & 54,174 & $12 \mathrm{C}$ & 0,98424 & 9,684 \\
\hline $61 \mathrm{C}$ & 0,91130 & 53,170 & $11 \mathrm{C}$ & 0,98537 & 8,867 \\
\hline $60 \mathrm{C}$ & 0,91351 & 52,172 & $10 \mathrm{C}$ & 0,98652 & 8,042 \\
\hline $59 \mathrm{C}$ & 0,91569 & 51,180 & $9 \mathrm{C}$ & 0,98770 & 7,237 \\
\hline $58 \mathrm{C}$ & 0,91784 & 50,313 & $8 \mathrm{C}$ & 0,98891 & 6,426 \\
\hline $57 \mathrm{C}$ & 0,91997 & 49,215 & $7 \mathrm{C}$ & 0,99016 & 5,615 \\
\hline $56 \mathrm{C}$ & 0,92209 & 48,241 & $6 \mathrm{C}$ & 0,99145 & 4,813 \\
\hline $55 \mathrm{C}$ & 0,92420 & 47,271 & $5 \mathrm{C}$ & 0,99277 & 4,000 \\
\hline $54 \mathrm{C}$ & 0,92630 & 46,307 & $4 \mathrm{C}$ & 0,99413 & 3,196 \\
\hline $53 \mathrm{C}$ & 0,92837 & 45,348 & $3 \mathrm{C}$ & 0,99552 & 2,394 \\
\hline $52 \mathrm{C}$ & 0,93042 & 44,394 & $2 \mathrm{C}$ & 0,99695 & 1,593 \\
\hline
\end{tabular}

Fonte: Adaptado de ANVISA, 2012. 


\section{EDITORA}

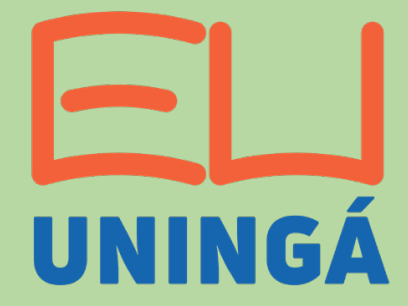

Editora UNINGÁ

PR 317, n. ${ }^{\circ}$ 6114, 87035-510, Maringá / Pr.

Fone: (44) 3033-5009

editora.uninga@uninga.edu.br

www.uninga.br/institucional/editora-uninga/ 